\title{
Uwagi na temat teoretycznych i metodologicznych aspektów pojęcia pola
}

\author{
Frédéric Lebaron
}

\begin{abstract}
Abstrakt: Tekst stanowi analizę pojęcia pola - jego granic i jego wagi zarówno w teorii Pierre’a Bourdieu, jak i w innych, ale odwołujących się do tej teorii, ujęciach socjologicznych. Swoje rozważania autor rozpoczyna od powrotu do genezy tego pojęcia w dziełach Bourdieu, czyli do okresu powstawania teorii, którego kulminacja przypada na lata siedemdziesiąte XX wieku. Następnie autor zajmuje się praktycznym zastosowaniem i empirycznym zakresem pojęcia pola. Na końcu przedstawia metodologiczne wykorzystanie pojęcia pola w ramach analizy danych.

Wyrażenia kluczowe: Pierre Bourdieu; teoria pól; dystynkcja; Max Weber.
\end{abstract}

Wystąpienie to jest dla mnie okazją powrotu do jednego z głównych zagadnień pojawiających się w debatach wokół Pierre’a Bourdieu - do problemu wagi i granic pojęcia pola.

O aktualności tej kwestii świadczy niedawna (2012) publikacja $A$ theory of fields [Teoria pola] Neila Fligsteina i Douga McAdama, książki będącej pierwszym teoretycznym ujęciem zakresu znaczeniowego pola w socjologii, nie licząc oczywiście Bourdieu, który jak wiemy, planował stworzenie ogólnej teorii pola i zapowiadał ją w wielu tekstach, jednak do dziś takiej publikacji nie mamy ${ }^{1}$.

Definiując pole jako porządek „mezospołeczny”, dwaj amerykańscy autorzy - jeden wywodzący się z obszaru socjologii ekonomicznej, drugi - socjologii ruchów społecznych (pamiętajmy, że u źródeł „socjologii organizacyjnej”, z którą obaj w mniejszym lub większym stopniu się związali, stoi stworzone przez Paula diMaggio (1991) pojęcie pola organizacyjnego) - uważają, że „strategiczne pola działania” (jak je nazywają) są elementami nieodzownymi do zrozumienia zarówno stabilności, jak i dynamiki globalnego porządku społecznego. A jest tak ze względu na działanie nowatorskich podmiotów (jednostek) wyposażonych w „społeczne kompetencje” i będących w ciągłym ruchu, nieustannie się sprzymierzających, działających wspólnie w obrębie pola i wciąż na nowo określających skomplikowane stosunki między różnymi polami.

Tak więc Fligstein i McAdam w swojej teorii pola nadają jeszcze silniejsze strukturalne znaczenie „strategiom” (czyli kompetencjom strategicznym) aktorów społecznych -

1 Fragmenty zapisu jego seminarium na temat pojęcia pola, prowadzonego w EHESS na początku lat siedemdziesiątych, zostaną wkrótce opublikowane w Actes de la recherche en sciences sociales. 
podkreślane już wcześniej przez Bourdieu w tekście o polu ekonomicznym - szczególnie tych dominujących w danym polu, oraz wadze wspólnej pracy organizacyjnej (ten element ich zdaniem Bourdieu zaniedbał, nie licząc jego książki o grandes écoles).

Ożywione dyskusje wokół pojęcia pola przekraczają zatem ramy teorii Bourdieu, a ich stawka we współczesnych naukach społecznych rośnie, chodzi bowiem o stworzenie teorii społecznych „podsystemów” (określenie pierwotnie raczej Parsonowskie czy Mertonowskie, lecz dość dobrze korespondujące z pozycją pola,jak ją widzą Fligstein i McAdam). Teoria ta pozwoliłaby przekroczyć zarówno makroskopowe schematy zachodzących zmian (np. ewolucjonistyczne), jak i charakterystyczną dla dzisiejszych czasów koncentrację na interakcjach czy stawkach na poziomie mikrospołecznym (widoczną zwłaszcza w „pogłębionych” pracach etnograficznych).

W moich rozważaniach chciałbym m.in. położyć nacisk na heurystyczny charakter pola jako narzędzia analizy empirycznej, przeciwstawiając się pewnego rodzaju „reifikacji” tego pojęcia, z którą dość często mamy dziś do czynienia. Użycie pojęcia pola w naukach społecznych jest przede wszystkim sposobem „postawienia problemu” czy, dokładniej rzecz ujmując, „skonstruowania przedmiotu” (Bourdieu, Chamboredon, \& Passeron, 1968).

Następnym krokiem w moich rozważaniach będzie zaznaczenie (może w sposób trochę osobisty) wielkiej wagi metodologicznych narzędzi analizy pól, które są ściśle związane z heurystycznym użyciem naszego pojęcia - chodzi o zgłębienie struktury i dynamiki przestrzeni społecznych. Dokładniej rzecz ujmując, odwołam się do matematycznej analizy danych (a przede wszystkim do wielowymiarowej analizy korespondencji i jej wariantów) jako praktycznego wykorzystania relacyjnej i przestrzennej koncepcji świata społecznego, z której Bourdieu uczynił początek, pierwszy etap formalizacji swojej teorii pola.

Całe znaczenie tej teorii ujawnia się ostatecznie dopiero w połączeniu obiektywnych i subiektywnych struktur („pozycje i zajęcie stanowiska”) określających pole, czyli w ustanowieniu pola jako porządku zasadniczo symbolicznego - nie tylko w uniwersum intelektualnym, w którym przeważają stawki symboliczne, lecz także w świecie polityki czy ekonomii.

W mojej prezentacji najpierw powrócę do genezy pojęcia w dziele Bourdieu, czyli do okresu, który można nazwać okresem powstawania teorii i którego szczyt przypada na lata siedemdziesiąte XX wieku. Następnie zajmę się praktycznym zastosowaniem i empirycznym zakresem pojęcia pola. Na końcu zaś krótko przedstawię metodologiczne wykorzystanie pojęcia pola w ramach analizy danych. 


\section{Elementy genezy pojęcia pola w dziele Pierre’a Bourdieu}

Pojęcia pola (pierwotnie związanego z fizyką) przedstawiciele nauk społecznych chociażby Kurt Lewin - używali już wcześniej, jednak dopiero Pierre Bourdieu przyznał mu czołowe miejsce w swojej konstrukcji teoretycznej i metodologii. Słowo „pole” pojawiło się najpierw w jego tekstach o Algierii, lecz jeszcze w mało specyficznym znaczeniu. Za to odwołania do poziomów „mezospołecznych” występują w tekstach Bourdieu często już od 1958 roku. Kapitalizm jest opisywany jako kosmos („świat”) narzucający swoje prawa społeczeństwu tradycyjnemu, które rządziło się zasadą honoru. Typowym przykładem względnie niezależnego podsystemu w świecie społecznym jest system edukacji. Właśnie ta względna autonomia stanowi podstawowy element uzasadniający pojęcie pola, stworzone w opozycji do analizy marksowskiej, przykrawającej wszystkie porządki społeczne tak, by pasowały do kategorii walk klasowych.

Jednakże jeszcze przed podjęciem tych tematów Bourdieu - wykorzystując optykę zarówno Durkheimowską i Maussowską, jak i strukturalistyczną - analizował „dom kabylski" jako przestrzeń skonstruowaną przez to, co społeczne. Wtedy po raz pierwszy uprzestrzennienie sfery społecznej odegrało poważną rolę w jego pracy. Później (przede wszystkim w L'anatomie du goût [Anatomia smaku] z 1976, a następnie w Dystynkcji z 1979 roku) pojawito się fundamentalne dla tego socjologa pojęcie przestrzeni społecznej.

Pole intelektualne i pole literackie były dla Bourdieu paradygmatami, od których wyszedł, wyznaczając własności pola w ogóle: względną niezależność oraz stosunki siły zwłaszcza symboliczne - między podmiotami działającymi. Pole jest tu rozumiane jako pole sił (analogia do pola w fizyce) i pole walki (model agonistyczny). A zważywszy że w walce chodzi też o konkurencyjność i monopol, na pole ma wpływ również model rynkowy.

Pojęcie pola krystalizuje się w latach sześćdziesiątych - najważniejsze artykuły na ten temat zostały opublikowane między 1966 a 1971 rokiem. Mamy tu na myśli: Champ intellectuel et projet créateur [Pole intelektualne i projekt twórczy] (Bourdieu, 1966), Champ du pouvoir, champ intellectuel et habitus de classe [Pole władzy, pole intelektualne i klasowy habitus] (Bourdieu, 1971a) oraz Une interprétation de la théorie de la religion selon Max Weber [Interpretacja teorii religii Maxa Webera] (Bourdieu, 1971b). Te czysto teoretyczne teksty prowadzą Bourdieu do zdefiniowania pola przez względną autonomię podprzestrzeni w łonie rzeczywistości społecznej: pole jest przestrzenią określoną przez stosunki między jednostkami wyposażonymi w obiektywne społeczne własności zapisane w habitusie.

Pierwszą ogólną teorię socjolog wypracował, wychodząc od przykładu pola religijnego, które wcześniej analizował Max Weber - zdaniem Bourdieu niekompletnie, bo z pominięciem faktu, że stosunki dominacji nie muszą się wiązać ze współoddziaływaniem czy bezpośrednią relacją władzy. Dlatego trzeba odwołać się do pojęcia dominacji

SLH 6/2017 | str. 3 z 13 
symbolicznej, niesprowadzalnej do narzucenia czegoś siłą fizyczną czy do „wpływu”. Przy okazji Bourdieu podkreślił także relacyjny (w sensie strukturalnym) wymiar pola. Tak więc to, czy dwa podmioty działania znają się nawzajem lub czy wchodzą w bezpośrednią interakcję, nie ma większego znaczenia, naprawdę liczy się tylko ich relacja strukturalna (abstrakcyjna, nieintuicyjna dla socjologa instytucji, który widzi tylko bezpośrednie relacje przywództwa i hierarchicznej władzy).

W Dystynkcji Bourdieu łączy swoją koncepcję przestrzeni społecznej (globalnej czy narodowej) z hipotezą dynamiki pól charakteryzowanych przez ich strukturalną homologię. Zarysowane tam pojęcia przestrzeni społecznej i pola wypływają bezpośrednio z ogólniejszej koncepcji („teorii społecznej”), wedle której społeczeństwo jest systemem obiektywnych relacji między podmiotami działającymi, określanymi przez swoje zróżnicowane i nierówne zasoby. Przestrzeń stylów życia, którą można obserwować, badając praktyki kulturowe, wynika ze struktury przestrzeni społecznej widzianej w perspektywie nierównej dystrybucji różnych rodzajów kapitału. Podstawowe pytanie, jakie stawia przed socjologią istnienie zróżnicowanej przestrzeni praktyk, opinii itd., jest pytaniem o ukrytą strukturę².

O ile przestrzeń społeczna, tak jak ją rozumie Bourdieu, zdaje się wewnętrznie związana z pojęciem habitusu, o tyle pole jawi się raczej jako teoretyczny instrument pozwalający badać specyficzne praktyki - takie jak sztuka, literatura, nauka - niedające się interpretować wyłącznie jako „odbicie” struktury klasowej.

Jakakolwiek podprzestrzeń nie jest jeszcze polem - potrzeba do tego minimalnego poziomu autonomii wobec globalnej przestrzeni społecznej’3. Strukturę globalnej przestrzeni społecznej znajdziemy w każdym polu, jednak zmodyfikowaną, przekształconą czy wręcz zupełnie przemienioną. Pojawia się tutaj metafora „refrakcji” (załamania w sensie optycznym), rozumiana oczywiście jako przeciwstawna wobec teorii „odbicia”. Im bardziej niezależne jest pole, tym poważniejsza refrakcja4.

Kolejna ważna myśl - struktura pola nie ogranicza się do bezpośrednich relacji między podmiotami działającymi; koncepcja, którą Bourdieu nazywał „interakcjonizmem”, rozwinięta w metodach empirycznych jako analiza sieciowa, nie wydawała mu się owocnym podejściem ${ }^{5}$. Ta ściśle określona koncepcja pola wyraża się $\mathrm{w}$ dostrzeżeniu i zbadaniu struktury różnych pól: intelektualnego (Bourdieu, 1966), religijnego (Bourdieu, 1971b), władzy (Bourdieu, 1971a), literackiego i filozoficznego (początek lat siedemdziesiątych), naukowego (Bourdieu, 1975), walki klasowej (Bourdieu, 1975), politycznego i ekonomicznego (Bourdieu, 1999), wydawniczego (Bourdieu, 1999) itd. Pojęcie klas dominujących,

2 Mamy tu do czynienia z teorią analizy danych, która w głównych osiach widzi wyraz ukrytych struktur danych.

3 Na przykład badana przez Monique de Saint-Martin przestrzeń szlachectwa nie ma wystarczającej autonomii, by potraktować ją jako pole w sensie ścisłym (Saint-Martin, 1993).

4 „Co do analizy zewnętrznej, to traktuje ona przedmioty kulturowe jako proste odbicie badź «symboliczny wyraz» świata społecznego (zgodnie z formułą Engelsa wyrażoną w odniesieniu do prawa), odsyła je bezpośrednio do społecznych charakterystyk autorów bądź grup, które są deklarowanymi lub też zakładanymi odbiorcami przedmiotów kulturowych i których przedmioty te mają być wyrazem" (Bourdieu, 2001, s. 311).

5 Bourdieu wrócił do osiemnastowiecznego sporu kartezjańczyków z newtonistami. 
od lat siedemdziesiątych coraz częściej rozumianych jako formujące „przestrzeń klas dominujących", zdecydowanie zostaje zastąpione przez pojęcie pola władzy (Bourdieu \& Boltanski, 1976) .

Z kolei każda podprzestrzeń społeczna może być badana zgodnie z logiką pól, to znaczy poprzez wywiedzenie jej obiektywnej struktury (wraz z formą, jaką przybiera w niej opozycja dominujących i zdominowanych itd.) i zinterpretowanie zaobserwowanych w związku z tą strukturą różnic w praktykach, zajmowaniu rozmaitych stanowisk itp. Mamy tu do czynienia z poszerzonym pojęciem pola, którego Bourdieu używa, mówiąc o „przedsiębiorstwie jako polu” (Bourdieu \& Saint-Martin, 1978) lub o „rodzinie jako polu" (Bourdieu, 1993). Chodzi więc o uniwersalny koncepcyjny instrument, pozwalający zrozumieć to, co społeczne, to znaczy zbiór właściwości dających się przetransponować na każdy obiekt społeczny.

Ogólna teoria pola, którą Bourdieu zapowiada w wielu tekstach, lecz która pozostała na etapie projektu, miała zuniwersalizować pojęcie (na wzór fizyki): pole tworzy się, kiedy jakiś społeczny podmiot działania wywiera efekt (pola) na inny podmiot. Zgodnie z tą logiką istniałyby pola bardzo niezależne (pola w sensie ścisłym), trwałe i globalne, oraz efekty pola (mniej trwałe i lokalne), pojawiające się od chwili nawiązania obiektywnej relacji między właściwościami podmiotów działających (która sama w sobie jest relatywnie stabilna).

\section{Klasyczne zastosowania pojęcia pola w zbiorowych $\mathrm{i}$ indywidualnych pracach empirycznych}

Pole jest dla Bourdieu ideą programową (,program dla..., jak widzimy w wypadku pola naukowego, którego teoria została wyłożona w artykule z 1975 roku, a następnie w dwóch niedługich publikacjach) i metodologiczną (w ten sposób można odczytywać bardziej teoretyczne analizy w Regułach sztuki lub - w sposób jeszcze bardziej pedagogiczny - w Zaproszeniu do socjologii refleksyjnej). W swoich seminariach Bourdieu raczej zniechęcał młodych badaczy do zbyt częstego używania pojęcia pola, a w każdym razie do używania automatycznego, szkolarskiego, do czego przedstawiciele nauk społecznych mają naturalną inklinację - bardzo szybko widzą „pole” wszędzie i przy każdej okazji, interpretując każdą społeczną rzeczywistość jako przejaw struktury pola. W ten sposób pojęcie się rozmywa.

Przypadek pola literackiego [we Francji] pod niemiecką okupacją pozwala postawić pytanie o autonomię pola w sytuacji bardzo silnych przymusów politycznych, a także militarnych. To przypadek niemal eksperymentalny, pozwalający ujawnić bardzo silną

\footnotetext{
6 Odosobnione pojęcie „pola walki klas” nie zostało rozwinięte, chociaż sam Bourdieu w wywiadzie udzielonym „La Nouvelle Critique” określił je - w bardzo althusserowskim języku - jako „ostatnią instancję” (Bourdieu, 1975).

7 Bourdieu często odnosił się do pola elektromagnetycznego, a nawet do ogólnej teorii względności.
} 
autonomię tej przestrzeni a contrario, mimo ograniczeń spowodowanych przez polityczne naciski (cenzura, promowanie autorów popierających rząd Vichy itd.). Przetrwała ona w specyficznej formie swojej produkcji i w swojej strukturze sytuację okupacyjną przede wszystkim dzięki rozwarstwieniu: uznani - pretendujący czy awangardowi, pokrywającym się z zajęciem stanowiska wobec reżimu.

Szczególnie interesujący jest zakres pola naukowego, stanowi ono bowiem społeczny mikrokosmos, wyposażony w najsilniejszą autonomię i najbardziej specyficzne struktury. Jeśli chodzi o analizę pola naukowego, najciekawszym odniesieniem są dziś badania Yves’a Gingrasa, związane z tradycją mertonowską, lecz odczytaną na nowo w kontekście Bourdieu (Gingras, 2012). Warto tu też przywołać prace Patrice’a Pinella na temat historii społecznej pola medycyny i jego rozważania o warunkach stosowania tego pojęcia ( $\mathrm{Pi}$ nell, 2012).

Od lat siedemdziesiątych (a dokładnie od 1971 roku) badania Bourdieu coraz bardziej kierują się w stronę po la władzy jako nowego sposobu analizowania przestrzeni klas dominujących (zwłaszcza opozycja doczesny - duchowy, władza - wiedza itd.), w przeciwieństwie do „socjografii elit”, jaką najczęściej uprawia się w międzynarodowych badaniach empirycznych (wystarczy przywołać chociażby klasyczny spór Dahla z Millsem).

Oryginalna koncepcja pola, pozwalająca rozwiązać problem różnych segmentów elit, doczekała się pierwszego poważnego opracowania w 1989 roku w La noblesse d'État, książce, w której Bourdieu rozwinął i empirycznie ugruntował hipotezę silnej homologii między polem władzy a polem grandes écoles (znajdujemy tu przeciwstawienie bieguna władzy doczesnej biegunowi władzy intelektualnej, Ecole Nationale d’Administration Ecole Normale Supérieure, i jego ewolucję). Zarówno teoretyczne ujęcie, jak i empiryczna analiza relacji tych dwóch podsystemów opierają się na idei homologiczności dwóch struktur: model został wypracowany w latach dziewięćdziesiątych podczas badania instytucji nauczania wyższego w kontekście „strategii reprodukcji” - badania prowadzonego pod kierunkiem Monique de Saint-Martin

W ten sposób zbiorowe, empiryczne badania świata społecznego poprzez analizę pól (czyli wciąż nabierający rozpędu teoretyczny, kolektywny program) stopniowo rozwijały się w różnych kierunkach - punkt wyjścia stanowiło oczywiście to, co Bourdieu nazwał „polem produkcji kulturalnej” (intelektualnej, literackiej, komiksowej, plastycznej, naukowej itd.), rozumianym zgodnie z „paradygmatem pola religijnego”, który pozwala zastanowić się nad tym, jaka jest stawka monopolizacji władzy symbolicznej, kto może decydować, co jest piękne, prawdziwe itd.

Pole władzy, a następnie pole polityczne (efemeryczna idea „pola walki klasowej” nie znalazła kontynuacji) pozwoliły na stopniowe przejście ku dziedzinom odpowiadającym właśnie biegunowi władzy „doczesnej” (socjologia elit, socjologia organizacji, socjologia

8 W latach dziewięćdziesiątych na seminarium prowadzonym w EHESS przez Monique de Saint-Martin miałem okazję zapoznać się z pracami G. Scarfy, N. Chmatki, B. Niane, M. R. Loureiry i innych. 
władzy itd.). Tak więc, przyjmując fundamentalną dla samej struktury pól opozycję, przeszliśmy od poziomu „duchowego” do „ziemskiego”, zaczynając od pola religijnego, a kończąc na ekonomicznym (oba ostatecznie okazują się związane). Łączy się to z wkładem Bourdieu w nauki polityczne, a także z odbiorem jego dzieła, na razie szczątkowym, przez ekonomię i zarządzanie.

Ostatnio mogliśmy zaobserwować pojawienie się wielu empirycznych prac dotyczących pól polityki publicznej, mocno inspirowanych ujęciem Bourdieu’owskim (podejścia, do którego uprawomocnienia przyczynił się Vincent Dubois). Przykładem mogą być badania „pola eurokracji” Didiera Georgakakisa (Strasburg), który tworzy „mapę” przestrzeni brukselskich instytucji, łącząc zdobycze neoinstytucjonalnych nauk politycznych z perspektywą pól. Podobne wpływy widać w pracach prowadzonych dziś przez zespoły związane z Antoine'em Vauchezem, Antoninem Cohenem, Guillaume'em Sacristem i innymi badaczami.

Pojęcie pola ekonomicznego, wyłożone przez Bourdieu w fundamentalnym z punktu widzenia tej teorii artykule z 1997 roku (najbardziej „sformalizowanym” i wchodzącym w dyskusję z teorią neoklasyczną), wraz z perspektywą otwartą przez „społeczne struktury ekonomii”, przeniknęło oczywiście do socjologii ekonomicznej, a następnie do prac o strategiach ekonomicznych (np. szefów banku centralnego). W moim przypadku wiązało się to z badaniami pola ekonomicznego jako pola naukowego. Pole ekonomistów „pokrywa” całą przestrzeń pola władzy i w pewnym sensie stanowi jego kwintesencję (Lebaron, 2000).

\section{Program badawczy: metodologia i praktyka}

Fligstein i McAdam oddzielają w swojej książce teorię pola od narzędzi metodologicznych pozwalających ją stosować, testować itd.; tymczasem właśnie tego Bourdieu radzit unikać. Byłbym skłonny trzymać się jego zalecenia, a nawet silniej niż on sam podkreślać rolę matematycznej formalizacji jako istotnego elementu tej perspektywy - zauważmy zresztą, że pojęcie pola wyłoniło się właśnie wtedy, kiedy Bourdieu i jego zespół (inżynier S. Bouhedja) przyswoili sobie narzędzia matematycznej analizy danych (Lebaron \& Le Roux, 2013).

Nie wyklucza to stosowania innych technik badań empirycznych, ale prowadzi do hierarchizacji/specjalizacji instrumentów wedle ich zdolności obiektywizacji (od bardziej strukturalnej do bardziej lokalnej). Tak więc obserwacja etnograficzna zdaje się fundamentalna jako procedura zbioru informacji dużo gęstszych i bardziej znaczących niż jakiekolwiek inne wykoncypowane metody (badanie eksperymentalne, ankieta czy nawet wywiad).

Pośród technik zbierania informacji użycie danych biograficznych (zbiór w zamierzeniu wyczerpujący) jawi się jako uprzywilejowany instrument analizy pól (wyrażenie „badanie

SLH 6/2017 | str. 7 z 13 
pola” jest używane w sensie „analiza danych prozopograficznych”). Dlatego pierwszym narzędziem analizy pola, jeśli chodzi o zdobycie informacji, jest systematyczne zbieranie danych biograficznych (co Bourdieu za historykami nazywa „metodą prozopograficzną”; por. Charle, 2001). Mocne argumenty na rzecz tej metody znajdziemy w artykule Le patronat (Bourdieu \& Saint-Martin, 1978), napisanym wspólnie przez Pierre’a Bourdieu i Monique Saint-Martin.

\section{Grandes écoles i klasy dominujące - badania empiryczne}

W roku akademickim 1966-1967 wśród studentów różnych szkół wyższych przeprowadzono badanie kwestionariuszowe nazwane „badaniem”. Zaowocowało ono licznymi publikacjami, z których najważniejsza była książka z 1989 roku. W niej pojawiła się idea bardziej systematycznej pracy nad różnymi odłamami klas dominujących: „niezwykle szybko okazało się, że nie sposób zrozumieć i wyjaśnić systemu, jeśli się nie zna systemu stanowisk, do jakich ich ukończenie prowadzi" (s. 78). Nie wystarczy już badanie wykonane na reprezentatywnej próbie, potrzebna jest systematyczna praca nad wyczerpującym w zamierzeniu zbiorem danych prozopograficznych: „pod warunkiem zebrania wszystkich rozproszonych informacji i zweryfikowania ich poprzez konfrontację źródeł oraz wszędzie, gdzie to tylko możliwe, przez zadanie bezpośrednich pytań lub wywiady z informatorami, możemy uzyskać zasadniczo większe i lepsze efekty niż przez bezpośrednie zastosowanie metody kwestionariuszowej. (W ten sposób postępowaliśmy z uporządkowanym zbiorem wywiadów - z dziennikarzami z prasy ekonomicznej, z szefami organizacji pracodawców, klubów itd.; prosiliśmy też o pomoc badaczy z INSEE specjalizujących się w dziedzinie przedsiębiorstw - praca ta wiele im zawdzięcza", s. 78). W tej perspektywie pierwszym kluczowym etapem jest zebranie informacji o biografiach i instytucjach. W badaniu „Patronat” zebrane informacje dotyczą „dyrektorów generalnych dwustu najważniejszych spółek przemysłowych i handlowych, uszeregowanych według wysokości kapitału własnego” (s. 78), „do czego dochodzą jeszcze dyrektorzy generalni znacjonalizowanych lub parapublicznych przedsiębiorstw usługowych [...], prezesi największych banków i zakładów ubezpieczeniowych". Ostatecznie przetworzono dane dotyczące 216 z 241 prezesów i dyrektorów, bo materiały na temat 25 pozostałych miały zbyt wiele luk. Informacje pochodziły z bardzo różnych źródeł: publikacji Dafsy, rocznika Desfossés-SEF dla spółek, roczników biograficznych, dokumentów prasowych itp. - to jeśli chodzi o dane czysto biograficzne. Nacisk kładziony na podmiot działający (a nie tylko na zmienne) ma uzasadnienie teoretyczne: „wprowadzając [do badania konkretne] osoby, możemy próbować ustalić to, co $\mathrm{w}$ funkcjonowaniu instytucji gospodarczych wydarza się tylko za ich pośrednictwem (przykładem mogą być te spółki o dziwacznie skomplikowanej strukturze, których jedynym czynnikiem łącznikiem jest osoba założyciela - Floirat, Béghin, Dassault czy Prouvost), nie zapominając przy tym, że jednostki - w tym, co najbardziej osobiste - są zasadniczo personifikacjami realnych lub potencjalnych wymogów wpisanych w strukturę pola czy - ściślej rzecz ujmując - w zajmowaną wewnątrz pola pozycję" (s. 7) (Bourdieu \& Saint Martin, 1978).

Po zebraniu danych trzeba jeszcze wiedzieć, jak je przetworzyć, by pozwoliły zanalizować dane pole.

Matematyczne modelowanie danych jest praktycznym narzędziem łączącym jakościową obiektywizację uzyskaną przez syntezę informacji statystycznych - w ujęciu bliskim analizie danych rozwiniętej przez Benzécriego - z polem w rozumieniu Bourdieu. 


\section{Badanie pt. „Pracodawcy” - przykład twórczego wykorzystania wielowymiarowej analizy korespondencji}

Autorzy badania uznali, że wielowymiarowa analiza korespondencji, użyta jako główne narzędzie, pozwoli odsłonić ukrytą rzeczywistość, która - choć nieuświadomiona - jest jednak bardziej „realna” niż cząstkowe spostrzeżenia i praktyki podmiotów działających.

Aktywne pytania (i modalności) zostały wyselekcjonowane ze zbioru danych biograficznych pozwalających scharakteryzować rodzaje kapitału, które są stawką w polu pracodawców. Modalności są pogrupowane w kategorie, a wiele z nich odnosi się do właściwości społecznych (od charakterystyki demograficznej do kariery szkolnej) i innych, związanych z polem ekonomicznym (stanowiska w radach dyrektorów, dystynkcje itd.). Wzięto pod uwagę przede wszystkim:

- miejsce zamieszkania;

- pochodzenie społeczne i rodzinę - zawód ojca, rangę we własnej klasie, obecność W „Bottin Mondain";

- przebieg edukacji (na przykład ukończenie jednego z prestiżowych paryskich liceów itp.);

- kompetencje zawodowe i przebieg kariery: przynależność do jednego z grands corps de l'État;

- specyficzna pozycja (stanowisko) zajmowana w polu (władza ekonomiczna, członkostwo w radach itd.);

- wskaźniki kapitału symbolicznego: oficjalne dystynkcje, odznaczenia itd.;

- wskaźniki przynależności do zorganizowanych grup (stowarzyszeń, klubów, organizacji zawodowych itp.).

Chmura jednostek została przedstawiona wraz z odpowiednimi nazwiskami, dzięki czemu czytelnik zyskuje bezpośrednią intuicję struktury pola.

Interpretowana przestrzeń jest trójwymiarowa, przy czym trzecia oś została opisana tylko pobieżnie w dodatku metodologicznym. Pierwsza oś przeciwstawia pozycje publiczne prywatnym (pole jest zdominowane przez menedżerów - technokratów, absolwentów Ecole nationale d'administration lub Polytechnique), druga, związana z czasem, przeciwstawia „nowo przybyłych” tym już „ustawionym”. Analiza daje nam wszechstronne wyobrażenie pola pracodawców ustrukturowanego przez relację do państwa (kapitał administracyjny) i przez dynamiczny proces współzawodnictwa poszczególnych frakcji, określonych przede wszystkim przez okres przynależności do pola (nowe pokolenie najczęściej kształciło się w szkołach handlowych itd.) (Bourdieu \& Saint Martin, 1978).

W analizie jest obecna perspektywa objaśniająca, zaś jej celem jest zrozumienie przestrzeni strategii menedżerskich (na przykład w związku z zasobami ludzkimi) w stosunku do pozycji zajmowanej w polu.W La noblesse d'État (Bourdieu, 1989) analiza ta jest przywołana i połączona z badaniem homologii między polem władzy (którego pole pracodawców jest podprzestrzenią) a polem grandes écoles.

Z praktyki Bourdieu można wydedukować czy wywieść ogólny program oparty na matematycznej analizie danych w socjologii. Artykuł Une révolution conservatrice dans 
l'édition [Rewolucja konserwatywna w świecie wydawniczym] (Bourdieu, 1999) można uznać za zaktualizowaną wersję tego ukrytego programu. To ostatnia praca, w której Bourdieu użył metod matematycznej analizy danych. Zrealizował ją wspólnie z Brigitte Le Roux i Henrym Rouanetem w ramach współpracy naukowców z dwóch zespołów, która zaczęła się po konferencji w Kolonii poświęconej empirycznym badaniom przestrzeni społecznej (1998).

\section{Pole wydawnicze (1999)}

Analiza matematyczna opiera się na danych prozopograficznych małej grupy wydawnictw publikujących dzieła literackie, $w$ tym przekłady z języków obcych. Podstawową użytą metodą jest wariant wielowymiarowej analizy korespondencji opracowany przez Brigitte Le Roux i Jeana Chiche’a. Technika ta pozwala badaczowi uznać pewne modalności pytań aktywnych za „bierne” (na przykład modalności niezawierające informacji lub zawierające informacje „śmieciowe”) w sposób nienaruszający pożądanej symetryczności metody.

Jako pytania aktywne Bourdieu wybiera rozmaite wskaźniki kapitału (symbolicznego, ekonomicznego i specyficznego dla danego pola). Bardziej ogólnie można by powiedzieć, że socjolog powinien stworzyć możliwie kompletną listę teoretycznie podstawowych wymiarów zasobów społecznych wchodzących w grę w badanym polu czy przestrzeni (w duchu drogiej Benzécriemu zasady). Do scharakteryzowania podgrup wydawców i sformułowania pytań o przyszłą dynamikę rynku (na przykład o przewidywany proces koncentracji, który doprowadzi do zmniejszenia liczby aktorów społecznych) mierzono odległości euklidesowe w przestrzeni wielowymiarowej analizy korespondencji (Bourdieu, 1999).

Interpretacja socjologiczna kładzie nacisk na „chiazmatyczną” strukturę pola wydawniczego, z główną opozycją: „wielkie” i „małe” (przeciwstawienie klasyczne dla tego typu danych), i drugą: komercyjne i publikujące literaturę ambitną. Ta druga oś okazuje się homologiczna z klasyczną osią opisującą rozkład kapitału zaobserwowany we wcześniejszych analizach (ekonomia versus kultura). Trzecia oś odnosi się do przekładów szczególnej wagi, co pozwala oddzielić dwa różne obszary bieguna komercyjnego.

Interpretacja socjologiczna kładzie nacisk na relacje między pozycjami (związane z konfiguracją zasobów) a zajmowaniem stanowiska (w tym wypadku idzie o wybory wydawnicze, lecz potencjalnie dotyczy to również wyborów politycznych, literackich czy naukowych, strategii i treści kulturowych); zaprezentowana tu interpretacja opiera się zasadniczo na jakościowych komentarzach analizujących chmurę badanych jednostek, stworzoną na podstawie zgromadzonych cytatów i wywiadów.

Możemy teraz streścić program badawczy oparty na przedstawionej perspektywie. Chodzi mianowicie o:

- zbadanie struktury pola lub, szerzej, specyficznej konfiguracji przestrzeni społecznej (ze statystycznego punktu widzenia pierwszeństwo mają procedury opisowe, którym mogą towarzyszyć dane zdobyte innymi metodami, takimi jak analiza sieciowa, wywiad etnograficzny itd.); 
- zbadanie strukturalnych homologii między różnymi polami i przestrzeniami społecznymi; badanie powinno się opierać na odpowiednich interpretacjach osi; analiza danych to praktyka interpretacyjna pozostawiająca miejsce na rozumowanie analogiczne do tego, jakie przeprowadza się w ramach ścisłych procedur statystycznych. Dalsze metaanalizy socjologiczne pozwolą skumulować rezultaty i skonfrontować się z badaniami podobnymi, które prowadzą do rozbieżnych wyników, oddzielić to, co uniwersalne, od tego, co specyficzne, sprecyzować historyczne i przestrzenne warianty, ogólne zasady itd.;

- określenie, jaka jest względna autonomia pól czy przestrzeni społecznych - co wymaga użycia metod porównawczych i hipotez przyczynowych celem zbadania relacji między polami (formalizacja relacji przyczynowych);

- zbadanie globalnej podprzestrzeni przestrzeni społecznej z zastosowaniem class specific MCA (wielowymiarowej analizy korespondencji specyficznej dla danej podchmury jednostek);

- wyjaśnienie praktyk społecznych i przyjmowanych stanowisk; zacytujmy Ludovica Lebarta: „statystyka niczego nie wyjaśnia, lecz dostarcza argumentów” (innymi słowy, pomaga znaleźć i ocenić możliwe wyjaśnienia socjologiczne);

- ustalenie znaczenia i hierarchii efektów pola; można tutaj połączyć analizę wariancji z metodą regresji w ramach matematycznej analizy danych, która zdaje się właściwsza w kontekście danych pochodzących z obserwacji;

- zbadanie dynamiki pól; pozwolą na to: klasyfikacja euklidesowa, odpowiednie zastosowanie składników resztowych i czynników strukturalnych oraz włączenie danych temporalnych (i różnych metod ich przetwarzania).

Teorii pola nie można zrozumieć w oderwaniu od jej praktycznych zastosowań w badaniach empirycznych, które z kolei pozwalają zdobyć wiedzę na temat - jak to określa Bourdieu - „ogólnych właściwości pola”. Brak wciąż najogólniejszych metaanaliz, które przyniosłyby wyniki i pozwoliły rozwinąć trwałe, niepodlegające nieustannym zmianom elementy teorii. Brak też socjohistorycznych badań charakterystycznych dla pól procesów ewolucyjnych (autonomizacja, różnicowanie się). Być może nadszedł czas, by zrealizować ten program.

Tłumaczyła Anastazja Dwulit

\section{Bibliografia}

Bourdieu, P. (1966, listopad). Champ intellectuel et projet créateur. Les Temps modernes, 1966(listopad), 865-906.

Bourdieu, P. (1971a). Champ du pouvoir, champ intellectuel et habitus de classe. Scolies: Cahiers de recherche de l'Ecole normale supérieur, 1971(1), 7-26.

SLH 6/2017 | str. 11 z 13 
Bourdieu, P. (1971b). Une interprétation de la théorie de la religion selon Max Weber. European Journal of Sociology / Archives Européennes de Sociologie / Europäisches Archiv für Soziologie, 12(1), 3-21.

Bourdieu, P. (1975). La spécificité du champ scientifique et les conditions sociales du progrès de la raison. Sociologie et sociétés, 7(1), 91-118. https://doi.org/10.7202/001089ar

Bourdieu, P. (1989). La noblesse d'État: Grandes écoles et esprit de corps. Paris: Minuit.

Bourdieu, P. (1993). À propos de la famille comme catégorie réalisée. Actes de la recherche en sciences sociales, 100(1), 32-36. https://doi.org/10.3406/arss.1993.3070

Bourdieu, P. (1999). Une révolution conservatrice dans l'édition. Actes de la recherche en sciences sociales, 126(1), 3-28. https://doi.org/10.3406/arss.1999.3278

Bourdieu, P. (2001). Reguły sztuki: Geneza i struktura pola literackiego (A. Zawadzki, Tłum.). Kraków: Universitas.

Bourdieu, P. (2005). Dystynkcja: Społeczna krytyka władzy sądzenia (P. Biłos, Tłum.). Warszawa: Wydawnictwo Naukowe Scholar.

Bourdieu, P., \& Boltanski, L. (1976). La production de l'idéologie dominante. Actes de la recherche en sciences sociales, 2(2), 3-73. https://doi.org/10.3406/arss.1976.3443

Bourdieu, P., \& Saint-Martin, M. de. (1976). L'anatomie du goût. Actes de la recherche en sciences sociales, 2(5), 2-81. https://doi.org/10.3406/arss.1976.3471

Bourdieu, P., \& Saint-Martin, M. de. (1978). Le patronat. Actes de la recherche en sciences sociales, 20(1), 3-82. https://doi.org/10.3406/arss.1978.2592

Bourdieu, P., Chamboredon, J.-C., \& Passeron, J.-C. (1968). Le métier de sociologue. Paris: Mouton.

Charle, C. (2001). Prosopography (collective biography). W International Encyclopedia of the Social and Behavioral Sciences (T. 18, ss. 12236-12241). Oxford: Elsevier Science Ltd. https://doi.org/10.1016/b0-08043076-7/02631-0

DiMaggio, P. J. (1991). Constructing an organizational field as a professional project: US art museums, 1920-1940. W W. W. Powell \& P.J. DiMaggio (Red.). The new institutionalism in organizational analysis (p. 67). Chicago: University of Chicago Press.

Fligstein, N., \& McAdam, D. (2012). A theory of fields. Oxford: Oxford University Press. https://doi. org/10.1093/acprof:oso/9780199859948.001.0001

Georgakakis, D. (Red.). (2012). Le champ de l'eurocratie. Paris: Economica.

Gingras, Y. (2012). Le champ scientifique. W F. Lebaron \& G. Mauger (Red.). Lectures de Pierre Bourdieu. (ss. 279-294). Paris: Ellipses.

Lebaron, F. (2000). La croyance économique: Les économistes entre science et politique. Paris: Le Seuil.

Lebaron, F., \& Le Roux, B. (2013). Géométrie du champ. Actes de la recherche en sciences sociales, 200(5), 106-109. https://doi.org/10.3917/arss.200.0106

Pinell ,P. (2012). À propos du champ médical: quelques réflexions sur les usages sociologiques du concept de champ. W F. Lebaron \& G. Mauger (Red.). Lectures de Pierre Bourdieu (ss. 305-318). Paris: Ellipses.

Saint-Martin, M. de. (1993). L'espace de la noblesse. Paris: Métailié. 
Some remarks on the theoretical and methodological aspects of the notion of field

Abstract: The text constitutes an analysis of the notion of field - its limits and its importance in the theory of Pierre Bourdieu and in other sociological approaches which draw on his theory. The author opens his considerations with a return to the genesis of the notion in Pierre Bourdieu's works, that is to the formative period of the theory, culminating in the 1970s. The author then goes on to ponder the practical application and empirical scope of the notion of field, and concludes the article with the presentation of a methodological use of the notion of field in data analysis.

Keywords: Pierre Bourdieu; theory of fields; distinction; Max Weber.

Citation: Lebaron, F. (2017). Uwagi na temat teoretycznych i metodologicznych aspektów pojęcia pola. Studia Litteraria et Historica, 2017(6). https://doi.org/10.11649/slh.1554.

This is an Open Access article distributed under the terms of the Creative Commons Attribution 3.0 PL License, which permits redistribution, commercial and non-commercial, provided that the article is properly cited. www.creativecommons.org/licenses/by/3.0/pl

(c) The Author(s) 2017

(c) To Polish translation: Anastazja Dwulit 2017

Publisher: Institute of Slavic Studies, Polish Academy of Sciences, Warsaw. Author: Frédéric Lebaron, École normale supérieure Paris-Saclay, Cachan. Correspondence: flebaron@yahoo.fr

The work has been prepared at author's own expense.

Competing interests: The author declares he has no competing interests. 